\title{
Psychodrama and Spirituality: A Practice-Friendly Review
}

\author{
Gökhan Özcan ${ }^{1}$ (1) \\ Marmara University
}

\begin{abstract}
Psychodrama is a set of widely-used philosophy, theories, and techniques on which J. L. Moreno laid the foundations. Moreno built his philosophy and practice on spiritual grounds from existential thought, theology, and texts about the relationship between God and man. This article aims to summarize the definition, basic process, and techniques of psychodrama, a group of psychotherapy methods, to reveal the relationship between Moreno philosophy and spirituality in different aspects and to examine Jungian Psychodrama, Souldrama, and the Therapeutic Spiral Model in this context as contemporary spirituallyoriented psychodrama approaches.
\end{abstract}

\section{Keywords}

Spirituality • Psychodrama $\bullet$ Moreno philosophy $\bullet$ Spiritually-oriented psychodrama approaches

Psikodrama ve Maneviyat: Uygulamacılara Yönelik bir Derleme

$\ddot{\mathrm{O} z}$

Psikodrama, J. L. Moreno'nun temellerini attığı, yaygın olarak kullanılan felsefe, kuram ve teknikler bütünüdür. Moreno, felsefesi ve pratiğini varoluşçu düşünceden, teolojiden ve Tanrı-insan ilişkisine dair metinlerden beslenerek, manevi bir zeminde inşa etmiștir. Bu makale, bir grup psikoterapi yöntemi olan psikodramanın tanımını, temel süreç ve tekniklerini özetlemeyi, Moreno felsefesi ile maneviyat arasındaki ilişkiyi farklı düzlemlerde açığa çıkartmayı ve bu bağlamda manevi yönelimli çağdaş psikodrama yaklaşımları olarak 'Jungiyen Psikodrama', 'Ruhsal Drama' ve 'Terapötik Spiral Model'i incelemeyi amaçlamaktadır.

\section{Anahtar Kelimeler}

Maneviyat • Psikodrama • Moreno felsefesi • Manevi yönelimli psikodrama yaklaşımları

\footnotetext{
1 Correspondence to: Gökhan Özcan, (PhD) Student, Marmara University, Email: fgokhanozcan@gmail.com Citation: Özcan, G. (2019). Psychodrama and spirituality: A practice-friendly review. Spiritual Psychology and Counseling 4, 39-55. http://dx.doi.org/10.12738/spc.2019.4.1.0058
} 
Psychodrama is based on the spontaneous experiential theater studies and clinical practice of its founder, psychiatrist Jacob Levy Moreno (1888-1974) in the early 1920s (Marineau, 1989; Tahar and Kellerman, 1996), and is a complex, powerful technique of group psychotherapy that encourages and develops clients' actions in life based on role play and self-presentation dramatization both verbally and nonverbally (Corsini \& Wedding, 1995; Kellerman, 1992; Nicholas, 2017; Rosenbaum \& Berger, 1963; Yalom, 1995).

Although psychodrama was first developed as a type of group psychotherapy, it is applied in different approaches and creative forms nowadays. As a sociodrama not focusing on the individual, psychodrama is used to evaluate and treat a wider social network (Blatner, 1996; Figusch, 2012) in couple and family therapies and in individual therapies performed by one or two co-therapists (Holmes, 2015). Meanwhile, psychodrama can be considered not only as a method of psychotherapy but also as a laboratory where psychosocial problems are explored through drama tools and participants' own behaviors. Hence, Moreno based the psychodrama principles and techniques on dramaturgical terminologies and practices (Blatner, 2000a; Jones, 1996; Scheiffele, 1997). As in theater, psychodrama has a scene where the play is acted out. A protagonist is the main actor of the work and one therapist as director guides the play; the auxiliary egos play the roles the protagonist wants to work on and the audience watches the play (Moreno, 1934).

Regardless of orientation, the psychodrama process consists of three stages: warmup, action, and sharing (Blatner, 2007). Moreno described the warm-up period as the protagonist's preparation process in putting one of his/her problems into words and treated the warm-up process as a therapeutic process of Spontaneity Theater and then contributed to transferring it into psychotherapy. The creative, aesthetic, and dramatic warm-up of theater transforms into therapeutic warm-up, which allows new behavior patterns to be experienced in life-like situations (Howie \& Bagnall, 2015). The warmup phase, which can be designed as forms of focusing on the here and now, breathing, walking, running, movement and mirroring exercises, Tai Chi, dancing, and physical games, strengthens unity, spontaneity, and creativity and also prepares the protagonist for the main play (Casson, 2004; Williams, 1991; Zoran, 2006).

The play (action) phase comes after the warm-up. In this phase, the protagonist may stage one or more events that have occurred in the past, are occurring currently, or will occur in the future. The main purpose of the protagonist study is to develop spontaneity and creativity in order to best meet new situations in life (Blatner \& Cukier, 2007; Gershoni, 2003; Tauvon, 2005).

Sharing, the last stage of psychodrama work, is when the auxiliary egos and the audience watching the play share their feelings after the protagonist's play. The 
purpose of the sharing phase is to normalize the protagonist's story by allowing for the possibilities of emotional discharge in the group, of making a mental picture of the situation being studied, of providing insight, and of showing that other group participants live experiences similar to the protagonist's (Karp, 2005; Leventon, 2001).

Briefly examining the therapeutic techniques of psychodrama after transferring the basic process is important. Role reversal is the most important technique of psychodrama. The protagonist has the opportunity to discover the other's position, experiences, thoughts, feelings, and behaviors through role reversal. An auxiliary ego chosen from the group replaces the protagonist's. Doubling, which is another technique from psychodrama, is when the group leader or audience expresses the protagonist's suppressed and unexpressed feelings and behaviors instead of the protagonist. The doubling technique encourages the process of empathy and gives the protagonist a lead for action. Using the mirror technique, the protagonist can choose an auxiliary ego for his/her role and can exit the scene and observe his/her life from the outside. Thus the protagonist can look at life from a distance and get the opportunity to make objective evaluations (Holmes, 1991; Wilkins, 1999).

\section{Moreno and Divinity}

Unlike the many philosophers of his time, Moreno did not divide the information fields he worked on into sections, instead claiming a consensus to exist between psychology, psychiatry, theology, philosophy, sociology, and their disciplines. For this reason, Moreno not only benefitted from psychiatry but also from existential philosophy (Howie, 2012), especially spirituality and theology (Lindqvist, 2005; Steere, 1997).

One can see traces of the existentialist-humanistic view in Moreno's perceptions of the human in his definition on being human as a free being who can self-define, develop, and enter into deep interactions. According to Moreno, a person's experiences are fundamental to potential. The essence of the experience is action, spontaneity, and being in the here and now. Human beings can embrace the universe, but at the same time they must accept their limited power (Dökmen, 2003).

The true and deep relationship which the existential philosopher Martin Buber (1878-1965; 1950) described as I-Thou (I-You), is a fundamental topic of Moreno's philosophy and practice. Moreno was influenced by Buber; Moreno evaluated relationships without conflict as fixed, predictable, and superficial and tried to construct opportunities for mutual authentic dialogue through psychodrama and sociometry (Apter, 2003; Waldl, 2005).

Moreno's interest in spirituality and theology can be attributed to a childhood memory. At the age of four, he proposed to his friends to play a game called 'God and 
His Angels' in the cellar of his home; he moved to the role of God, and his friends asked him why he was unable to fly and encouraged him to do so. In response, he flew himself down from his chair and broke his shoulder (Moreno, 1946). He considered this moment to be the spiritual moment in which he discovered psychodrama and its basic tools (Scategni, 2002).

Moreno emphasized the creativity and spontaneity of the cosmos in his texts; he regarded the term cosmos not only as the physical universe but also as the much larger dimensions of the soul (i.e., wisdom, experience, and imagination). Thus he considered the soul as an expression of God's action and fundamental nature. For him, God is theologically a creative and spontaneous being (Blatner, 2000a).

In his book, Words of the Father (1971), Moreno said that God was not a being who created and then departed, as described in some religious texts; he said that God creates every moment and that every person has the power to participate in God's creation through their actions and spontaneity. Moreno, who considered creativity as a divine power spreading over the cosmos, presented a philosophy that can be extended over religion, even to all religions. Here one encounters a view of an aesthetic, active, and immanent God instead of the God of history or religion that punishes and rewards. Moreno is based on the I-God consciousness, unlike a transcendent God-consciousness, which has been revealed as the He-God and ThouGod throughout history. I-God emphasizes the creative aspect that is active in action and potentially present in every human being (Borgatta, Boguslaw, \& Haskel, 1975; Blatner, 2000b; Johnson, 1948; Kraus, 1984).

Moreno stated psychodrama to have an eventual and spiritually-healing level called cosmic catharsis, claiming that the individual goes beyond the given reality through cosmic catharsis. For example, in psychodrama, a man can be a woman or a person can animate an animal or dead person. In this way, when individuals get out of themselves and discover the visible and invisible aspects of the cosmos, they can experience coexistence and thus healing in the universe (Garcia \& Buchanan, 2009).

\section{Current Efforts in the Relation of Psychodrama and Spirituality}

The spiritual aspects on which Moreno based psychodrama have important parts as they are fed from theology and are still being researched by modern authors. Blatner (2000b, 2005b) examined the cabbalistic, mystical, and archetypical elements in Moreno's philosophy and claimed psychodrama to be a mythical journey. Thus, psychodramatists should also take on the role of director of rites in addition to the roles of leader, director, and therapist that they already have. According to Blatner, by playing a spiritual role, the psychodramatist becomes the one who tries to relate the group's existence to its greater integrity and also the one who can say things like, 
"We have gathered here for spiritual purposes to help each other, to love, and to make our group members stronger, freer, and wiser."

While explaining the theory of the role that the foundations of psychodrama are based on, Moreno (1961) described roles in triplet: our physiological activities in life as psychosomatic roles, our social relationships as social roles, and psychological selfaspects as psychodramatic roles. Natalie Winters (2000), a psychodrama practitioner and theoretician, stated in her article, Fourth Role Category, that the psychospiritual role in Moreno's role theory is incomplete. According to her, the psychospiritual role includes functions such as dreaming, being receivers, remembering, being givers, believing, and praying. Psychodrama leaders who adopt a psychospiritual role can invite the group to experience universal intelligence, wisdom, divinity and the present.

Emphasis on the spiritual aspects of psychodrama has not only been made by psychodramatists. For example, Thomas Moore (1994, 1996), an American Jungian philosopher, researched the nature of the soul; he described the soul as a personal and professional development opportunity and stated psychodrama and playback theater to enable one to open the heart and live the soul because of its philosophical background and techniques.

As Moreno (1947) tele is a negative or positive social relation configuration in bilateral relations and is thought to have a spiritual aspect. The key element of tele is its reciprocity that reflects the human capacity to perceive or imagine how other people feel about a relationship (Moreno, 1956). When a group is created, all members have a potential tele structure that includes their personal history prior to the group coming together. This constitutes the basis for the active tele structure that will later develop (Zuretti, 2005). During the action in psychodrama, a protagonist chooses an auxiliary ego to portray anything from his/her life, and the common aspects the chosen person has with the chosen role are recognized during or after the play. Here, the tele process occurs with rapid identification (Yaniv, 2014). Studies examining the tele phenomenon in relation to quantum psychology have enriched the literature on the relationship of psychodrama and spirituality with new scientific developments (Hammer, 2000; Wolinsky, 1991; Zohar \& Marshall, 1990).

As an effective example of an attempt to reconcile psychodrama with different schools of psychology, Goldberg (2009) focused on the relationship between psychodrama theory/ practice and positive psychology, examining the overlooked parts of Moreno's original work and emphasizing the strengths, virtues, and geniuses in each individual using a positive psychodrama approach.

In the literature, the presence of religiously-oriented psychodrama studies is remarkable in addition to those on spirituality. In this way, Pitzele (1991) tried to 
integrate psychodrama into tales from the Torah and called psychodrama a window/ mirror of soul and a spiritual instrument of truth for the human being; Meyer (2012) aimed to evaluate and organize religious and spiritual perceptions through drama by applying religious-oriented drama therapy on students from different religions. Frick (2013) examined the use of psychodrama in Christian biblical-drama sessions, which parallel Moreno's and Christian author Ignatius's (35-108 A.D.) thoughts; Frick used the psychodramatic role-reversal technique in the biblical-drama.

Quantitative and qualitative studies are found investigating the relationship between psychodrama and spirituality, as well as theoretical and practical approaches. In one reported case study, Perrotta (2012) conducted psychotherapy sessions using a predominantly Jungian psychodrama-oriented dream work for a female client with a history of violence and emotional conflicts in her family history; Perrotta stated that, at the end of the process, significant developments had occurred in the roles in the client's life and in her individualization orientations. Tavakoly, Namdari, and Esmaili (2014) reported that the psychodrama group in their quasi-experimental study conducted with 32 women differed significantly from the control group in terms of spiritual well-being. Salehi and Shokri (2016) found the group participating in the psychodrama-oriented group consultation to differ in terms of intrepidity and mental intelligence compared to the control group in a full experimental study with 60 female high school students.

\section{Contemporary Spiritually-Oriented Psychodrama Approaches}

Classical (Morenian) psychodrama has been developed and enriched with the technical and practical interventions of the following psychodrama practitioners. The most important approaches to spiritual orientation are: Jungian psychodrama, soul drama, and the therapeutic spiral model.

1. Jungian psychodrama. This approach was created by integrating Jung's analytic theory into psychodrama. It was developed by the Italian psychology professor and Jungian psycho dramatist, Maurizio Gasseau (Gasseau \& Gasca, 1991). The theoretical framework in Jungian psychodrama is structured on the concepts of Jung's (2014) depth psychology, dreams, archetypes, collective unconscious, and individualization process.

Different from that of classical psychodrama, the stage in Jungian psychodrama sessions forms a full circle. Plays are acted within this circle because, in Jungian thought, the circle is the archetype of fullness and thus attempts to provide the group with integrity (Jung, 2017). In the case of Jungian Psychodrama, the value of role reversal as a therapeutic psychodrama technique is that one faces one's antagonist-or in Jungian terminology, one's shadow-while playing a different role. The shadow 
is the unconscious part that the individual rejects and does not desire (Jung, 1969). The protagonist has the chance to meet his/her shadow while experiencing another role in the role reversal technique, and one takes the opportunity to step toward individualization and realize one's inner thoughts while paired by the group leader in the doubling technique (Gasseau \& Scategni, 2007).

At the beginning of a Jungian psychodrama session, the group leader tries to gather participants' dreams and images of the past or future (Gasseau \& Perrotta, 2013). Dreams are the most extensively studied subject in Jungian psychodrama and correspond exactly to the drama's structure (Jung, 1934). All types of dreams are handled in Jungian psychodrama: prediction dreams, nightmares, recurrent dreams, symbolic dreams, social dreams, and dreams of the future (Scategni, 1994, 2001, 2002). Before starting the dream work, participants are encouraged to try to remember imagery from dreams using Gasseau's semi-hypnotic experience inspired by the ancient practices of Asclepeion, the dream incubation technique that accompanied by a Tibetan bell. In this direction, dreams are worked on together through the connotations of the protagonist's past experiences. After working on a dream or any other experience, the group leader takes the role of observer and makes narrative observations. In this part, the leader brings the distinctive aspects of the dream to archetypal and hermetic descriptions without departing from the dream phenomenon, and, if necessary, comments on the collective unconscious of the group in the context of this dream (Gasseau \& Gasca, 1991).

In Jungian psychodrama, dreams are not only studied individually but also as a group. The dream that a person talks about evokes another person's dream, and by arousing different dream associations in another person, a chain of associations is formed and a phenomenon termed the social dream matrix occurs. In this stage of the Jungian psychodrama, these associations are acted out in order; a matrix is formed from these associations, ultimately attempting to reveal and interpret the collective unconsciousness of the group (Lawrence, 2003; Tatham \& Morgan, 2018). With its ceremonial and shamanic experiences, Jungian psychodrama is an orientation where surplus reality is worked intensively. Surplus reality is the realization of fantasies and future thoughts in the here and now of the psychodrama stage (Moreno, Blomkvist, \& Rutzel, 2013). For example, a protagonist in the mourning process can be allowed to switch to the role of the deceased and send one's self messages, then return to the original role and receive these messages (Gasseau \& Scategni, 2007). 


\subsection{Case Study. A section from the dream work of Ms. T ( age 24): ${ }^{*}$}

A storm is coming. A Tweety-bird blanket hangs on the balcony from my home, I loved this blanket very much in my childhood. There is also a flower-figured sheet with a pair of red wet socks hanging from it. My mom tells me to take them in because of the storm, and I tell her that I'll take them in later. After a while I look at the sheets and socks on the balcony from inside the house. The Tweety-bird blanket has fallen to the ground and the other one has flown away. My mother brought only the red socks in. I think I couldn't get out because of the storm, and I feel angry at my mother for not taking my blanket in.

After telling her dream, Ms. T was invited to the middle of the group by the group director. The group director stood next to her in a supportive manner and asked her if there had been any storms in her life in recent years. Ms. T mentioned that maybe it is the break up with her boyfriend whom she had been together with for three years. Her boyfriend had gone abroad for academic reasons and their relation was forced to finish because of that.

The director asked Ms. T to choose someone from the group for her boyfriend's role. Ms. T created a scene in which she and her boyfriend talked about their relationship in the park. The manager gave Ms. T the opportunity to tell her boyfriend the things she had wanted but been unable to say in real life, and she said this: "This country's system is bad, but not as bad as you think. You don't have to go. I am angry with you because there is no place for me in the future you have established for yourself." The scene closed, and the director offered to return to the dream, asking her to choose people from the group for the roles of the red socks, the Tweety blanket, the other sheet, the mother, and the storm. The dream began to be relived from the beginning. The scene was ended after the following sentence from Ms. T: "My favorite sheet has gone. I can't take it in, it's very cold outside." Here, Ms. T was asked to make associations. Ms. T remembered that her mother used to read her Little Red Riding Hood as a child. The outside was dangerous because of the storm, and this evoked the memory of the forest being dangerous for Little Red Riding Hood. Ms. T chose the role of mother for someone in the group and listened to this tale from her mother. She changed the role and became her mother, and the scene was relived. While the tale was being told, the scene was stopped at the moment when the hunter came in to save the little girl, and Ms. T was doubled (doubling technique) by the director with the following sentences:

There's no one in my life to read a tale for me. My boyfriend's leaving. I feel like my love story is stolen. My boyfriend is not a good hunter. My Tweety blanket has also gone. This situation is not easy at all for me.

\footnotetext{
* This case study was conducted by the Institute for Psychodrama, Sociodrama and Community Mental Health, on 28-30 September 2018 by Prof. Dr. Maurizio Gasseau \& Prof. Dr. Ali Babaoğlu from the session of FEPTO (European Psychodrama Federation) accredited Analytical Psychology and Jungian Psychodrama and has been reported by changing some information in order to protect the personal rights of the participant.
} 
This doubling was very meaningful to Ms. T, and she started to cry. The director offered to return to the dream again and asked her to end the dream as she wanted. Ms. T went to the balcony, took the Tweety blanket and embraced it, then ended the work. After the dream work, people who had taken roles in the dream work shared. Then in the narrative observation the director said:

\begin{abstract}
It was interesting for you to remember the Little Red Riding Hood tale since this tale is about erotic emotions. She's about to be seduced, beaten, fooled, etc. The wolf perhaps represents the men in your life and your boyfriend. It may represent not only your boyfriend but also your complicated feelings about your boyfriend's leaving. Meanwhile, the blankets may represent a love affair because there were two sheets: one of them flew because of the storm and the other one fell to the ground. Just like you and your boyfriend. The fall of the Tweety blanket to the ground was like your childhood walking away from you.
\end{abstract}

Ms. T worked on her dream and some memories from her past and present on a Jungian psychodrama stage using this dream. The facts that the dream phenomenon has a metaphysical value different from the structure of the physical world and that the dream is associated with active images from the point of creativity have brought this work to a spiritual axis.

1. Souldrama. Developed by American psychodramatist Connie Miller (2000, 2004), souldrama is an approach based on the concepts of spirituality and spiritual intelligence, which help one realize higher aims by regulating the ego and spirit. It is a type of intelligence on problems related to spiritual intelligence, meaning, and values that question how one can live life in a larger, richer, more meaningful way. It is used in defining and regulating the skills and abilities necessary for the adaptive use of spirituality (Emmons, 2000; Zohar \& Marshall, 2000).

Souldrama is concerned with Moreno's emphasis on the concept of divinity and claims that psychodrama actually focuses on promoting mental intelligence and spirituality. With the inclusion of spirituality in therapy, clients can obtain the necessary spiritual energy to make life changes (Miller, 2007). Souldrama proposes a seven-phase spiritual discovery process, each stage is overcome by the cover metaphor, by passing each cover forward, a new phase of spiritual consciousness is introduced (Miller, 2000, 2004).

The first session is called faith, and the second session is called truth. These deal with rational intelligence. In the faith session, basic trust is provided through prayer, and in the truth session, participants try to find out what skills their parents bestowed on them in order to discover their higher goals. The third session is mercy, and the fourth session is called love. These are based on emotional intelligence. Participants can switch to the role of God and explore ways to be empathetic with the people they know; in the love session, they discover the personal meanings of love, unconditional 
love, and acceptance through the active image technique. The last two sessions attempt to develop mental intelligence. While the fifth session, called modesty, aims to balance one's sense of trust with self-confidence and modesty in order to appreciate people's diversity to learn the value of being faithful to one's beliefs, the sixth session, thankfulness, invites participants to think deeply about their self-worth and gratitude. In integration, the seventh and final session, participants experience the moment, listen to the spirit, and begin to be creative with God. This stage is where this transformation and the three different intelligences combine (Miller, 2008, 2010). Souldrama also is used in twelve steps in the treatment of alcohol addiction in the clinical environment (Miller, 2013).

3. Case Study. This section is about Mr. J. He is 45 years old, newly divorced, and has worked for 20 years at the same job with his wife. Setting up his own business recently and struggling to cope with the financial crisis, Mr. $\mathrm{J}$ is having problems with his current relationships with women. For Mr. J, two phases were designed represented by covers. The first cover is the discovery of the soul's task. In this phase, Mr. J was introduced to his mother's soul on the psychodrama stage in order to deal with the problems he had had with his mother. ${ }^{* *}$

Firstly, a statue was made of the way his mother showed her love to Mr. J when she was alive. His mother wants him to light a candle. Mr. J is looking back at her over his shoulder.

Protagonist: (to the mother's soul) You were bitter.

Mother's Soul: I didn't know how to love.

Protagonist: I had to listen and take your sorrowful sentences. Even though I hated to listen to them, I wanted to listen to understand what was going on in the family. That was my way of controlling things. We had to move because we had gone bankrupt. I had to leave home but I never wanted to do it. I had wanted to stop your sorrow.

Mother's Soul: I apologize.

Mr. J's Guardian Angel brought a book, The Task of My Spirit. Mr. J reads from the book:

My job is to design houses in which people can live happily and peacefully. The guardian angel repeats this.

Guardian Angel: Explain to your mother how you tried to stop her sorrow.

Protagonist: I tried to stop your sorrow by desiring to make a house where you and I could stay together. That's what I'm doing as a profession now, building safe areas. Thank you

\footnotetext{
** This case study is quoted from Case A in Conny Miller's (2000, p. 181) article The Technique of Souldrama $\mathbb{R}$ and Its Applications. Some expressive changes have been made to protect the integrity of the style in the article. The session was directed by Conny Miller.
} 
for helping me with this. I'm trying to make a connection with your love, by sculpting your sorrow. I couldn't build anything without feeling sorrow. Thank you for giving me this gift I use every day in my job.

In order to solve his problems with women, Mr. J had to first face his mother in Souldrama. His attempt to accept the feelings of sorrow that his mother had caused him, the spiritual message from the Guardian Angel (auxiliary ego), and calling this whole process the Discovery of Soul's Task suggest that this case study has a spiritual texture.

3. Therapeutic spiral model (TSM). This approach was adapted to the psychodrama clinic by M. Katherine Hudgins (2002) in order to ensure safe and qualified work on clients with traumatic experiences. The scientific theoretical orientation of this model is based on trauma neurobiology; cognitive behavioral therapy's understanding of the mind, attachment, and object relations theory; Morenian spontaneity; creativity concepts; and role theory (Hudgins, 2007).

The spiral metaphor in the name of the approach was created by Hudgins as a spiritual image inspired by the healing symbols of American, New Zealand, and Australian natives and African, South Americas, and Korean shamans.

Accordingly, spiral energy is a way for spiritual chaos to begin to decrease, and clients should take the spiral one step at a time to consciously control the mental hurricane. It is an effective metaphor that helps create realistic goals and cognitive meanings through the act of re-understanding perceptions and belief systems impaired by trauma. The TSM aims to create positive role voices that can be personalized according to clients' spiritual resources and symbolizes this effort as psychotherapeutic heart surgery (Hudgins \& Toscani, 2013).

The TSM proposes some prescription roles for strengthening the self-organization of a client who has had a traumatic experience: the observer ego, inner-soul strength, client role, interpersonal strength, over strength, body match, inclusive match, and director of defense. These roles can be undertaken by the psychodrama manager to support the client (Hudgins, 2002). In particular, the roles of inner-soul strength and over strength are thought to have spiritual sides.

2.1. Case Study. This is a portion of the beginning of the trauma work executed by the protagonist, Mei Feng, a middle-aged TSM group member in Nantou, Taiwan who wishes to gather strength to abandon her abusive husband. ${ }^{* * *}$

Mei Feng bursts into tears as she begins walking and is then able to speak to form the session contract. She says: "I'm even afraid to work on this problem. I am afraid

*** This case study is from an article published in Kate Hudgins' book Psychodrama: Advances in Theory and Practice' (pp. 176-177). Some of the quoted statements have been changed to preserve its style integrity. 
he will understand what I am doing." The client's limbic system has captured her cognitive functions, and she loses the ability to remain in the here and now in the moment. Rather than directing her to the past, clinical attempts are made to enable TSM to exercise prescribed roles effectively in order to consolidate self-organization and to increase her spontaneity. The clinician, as a director, attempts to stop the trauma spiral that lowers the unprocessed right-brain scans, taking over the power and connections they need, the sensations, body memories, and intensive affect and coping skills needed to survive. The psychodrama director steps in as her body match in order to increase her active bodily awareness and to focus her attention on the now.

The director made the following supportive statement to the protagonist:

We should stop right here and get some strength and support for you so that you can face some fear of being hurt by your husband. Take a few deep breaths to prepare yourself. I' $m$ going to stand next to you, and help you stay at now as your body match. I'm talking to the first person you have, to your auxiliary side. The one that helps you stay safe now. All right?

The protagonist makes a silent okay sign.

The director stands beside the protagonist as her body match and starts to speak:

I'm taking a few deep breaths... and... As I'm doing this... my mind is getting slower... I'm looking at this room. I'm in the social services TSM group. I'm safe. Silence... breathes... Maybe I can imagine a strong, solid tree in my dream. I feel my roots beneath the ground. Yes... here... better... I'm a big, strong tree, I've been through a lot of storms and I'm still up.

Protagonist: I can slow down. Yeah, I see the room and I see the other people in the group. I feel... myself... as a tree... a Chinese tree... I've been here for 3000 years... I've given solace to many people (lightened their sorrow) and connected to the earth with strong roots.

Director: Good, choose someone to be a tree and we shall embody it as an over strength. If you meet your fears today, it's something you need. Also, I will ask you to choose someone to be your body match who can walk with you during the drama.

The phase continued using prescription roles until her self-organization strengthened and her spontaneity increased. Mei Feng's primary intention was to gain her spiritual power through TSM in order to face her abusive husband on the psychodrama stage. Mei Feng was supported by the director's spiritual sensitivity. Discussing the neurological structure and somatic signs of trauma experienced by Mei Feng with spiral metaphors and reviving the image of an ancient, curative tree in order for her to gain her inner soul strength have been evaluated as interventions with spiritual aspects. 


\section{Conclusion}

Psychodrama has a wide and rich perspective that cannot be limited only as a therapeutic tool in treating psychological symptoms. Moreno was ingeniously able to perceive and convey the influence of spirituality and religion on human beings and life, despite the contrary ideas and criticisms of his time. The most important points that make Moreno's ideas valuable are how he associates the notions of spontaneity and creativity with God directly and his ability to indicate the infinite power and boundaries of human potential without departing from the scientific developments of his age as he places the perception of God at an aesthetic level with the idea of I-God. Contemporary researchers have also notably dealt with Moreno's legacy of thought along different axes in spiritual and religious contexts.

Placing dreams, which are space-less and timeless, and the individual and collective unconscious onto its main axis and using Jungian archetypes, myths, and alchemy as an interpretation tool in the narrative-observation stage allow Jungian psychodrama to be considered as having a spiritually sound framework. The spiritual core of the Jungian psychodrama that stands out with its focused practice deepens and enriches its dream work, which is also considered in classical psychodrama. Eastern mysticism is integrated into psychodrama through the dream incubation technique.

Souldrama has a terminology and practice directly oriented at spirituality. The intense usage of spiritual metaphors is an important contribution of Souldrama to classical psychodrama. However, its application based on a protocol consisting of phases increases the risk of the protagonist reducing creativity and spontaneity; thus Souldrama must be considered to have some limitations.

The Therapeutic Spiral Model, however, can be considered a strong approach with its indications in treating trauma by reason of its shamanic origin: caring for the client's spiritual resources and aiming to transform meaning.

Rather than considering the decisiveness of theoretical framework and forms of intervention on the functionality of these three spiritually-oriented approaches, clients' expectations and needs, personality traits, and whether or not they find the approach meaningful are considered to be more decisive factors.

Although psychodrama is a therapeutic tool with widespread use in Turkey, academic studies focusing on the spiritual aspects of Moreno's philosophy and psychodrama are found to be quite limited. In light of this article, a need exists for studies where psychodrama can be considered together with the Sufism discipline, which is the aesthetic dimension of Islamic thought. This article is hoped to encourage new articles on the relevance between psychodrama and spirituality. 


\section{References}

Apter, N. (2003). The human being: JL Moreno's vision in psychodrama. International Journal of Psychotherapy, 8(1), 31-36.

Blatner, A. (1996). Acting in: Practical applications of psychodramatic methods. New York: Springer.

Blatner, A. (2000a). A new role for psychodramatists: Master of ceremonies. Journal of Group Psychotherapy, Psychodrama and Sociometry, 53(2), 86.

Blatner, A. (2000b). Foundation of psychodrama history theory and practice. New York: Springer.

Blatner, A. (2005a). Perspectives on Moreno, psychodrama, and creativity. Journal of Creativity in Mental Health, 1(2), 111-121.

Blatner, A. (2005b). Role theory, archetypes, and Moreno's philosophy illuminated by the kabbalistic Tree of Life. Journal of Group Psychotherapy, Psychodrama and Sociometry, 58(1), 3-14.

Blatner, A. (2007). Morenian approaches: Recognizing psychodrama's many facets. Journal of Group Psychotherapy, Psychodrama and Sociometry, 59(4), 159-170.

Blatner, A. \& Cukier, R. (2007). Moreno's basic concepts. C. Baim, J. Burmeister, \& M. Maciel (Ed.), Psychodrama: Advances in theory and practice (pp. 293-307). London: Routledge.

Borgatta, E. F., Boguslaw, R., \& Haskell, M. R. (1975). On the work of Jacob L. Moreno.

Sociometry, 38(1), 148-161.

Buber, M. (1950). I and thou (R. G. Smith, Trans.). London: T. \& T. Clark. Casson, J. (2004). Drama, psychotherapy and psychosis. East Sussex: Routledge.

Corsini, R., \& Wedding, D. (1995). Current psychotherapies. Itasca: F. E. Peacock.

Dökmen, Ü. (2003). Sosyometri ve Psikodrama [Sociometry and psychodrama]. Istanbul: Sistem.

Emmons, R. A. (2000). Is spirituality an intelligence? Motivation, cognition, and the psychology of ultimate concern. The International Journal for the Psychology of Religion, 10(1), 3-26.

Figusch, Z. (Ed.) (2012). From one-to-one psychodrama to large group socio-psychodrama. Maidstone: Lulu.

Frick, E. (2003). Psychodrama and the spiritual exercises. The Way, 42(3), 151-160.

Garcia, A., \& Buchanan, D. R. (2009). Psychodrama. E. R. Johnson, D. Read (Ed.), Current approaches in drama therapy (pp. 393-423). Springfield: Charles C Thomas.

Gasseau, M., \& Gasca, G. (1991) Lo Psicodramma Junghiano. Torino: Boringhieri.

Gasseau, M., \& Scategni, W. (2007). Jungian psychodrama: from theoretical to creative roots.

C. Baim, J. Burmeister, \& M. Maciel (Ed.), Psychodrama: Advances in theory and practice

(pp. 261-271). London: Routledge.

Gershoni, J. (2003). Psychodrama in the 21st century: Clinical and educational applications. New York: Springer

Goldberg, M. C. (2009). Positive Psychodrama and the early works of JL Moreno. Group, 33(4), 359-372.

Hammer, R. D. (2000). New approaches to psychodrama. Journal of Group Psychotherapy, Psychodrama and Sociometry, 52(4), 155-161.

Holmes, P. (1991). Classical psychodrama: An overview. P. Holmes, \& M. Karp (Ed.), Psychodrama: Inspiration and technique (pp. 7-13). London: Routledge.

Holmes, P. (2015). The inner world outside: Object relations theory and psychodrama. New York: Routledge. 
Howie, P. C. (2012). Philosophy of life: JL Moreno's revolutionary philosophical underpinnings of psychodrama and group psychotherapy. Philosophy and Group Psychotherapy, 36(2), 135-146.

Howie, P. C., \& Bagnall, R. (2015). The transmogrification of warm-up: From drama to psychodrama. The Arts in Psychotherapy, 44, 35-44.

Hudgins, M. K. (2002). Experiential treatment for PTSD The Therapeutic Spiral Model. New York: Springer.

Hudgins, M. K. (2007). Clinical foundations of the Therapeutic Spiral Model: Theoretical orientations and principles of change. C. Baim, J. Burmeister, \& M. Maciel (Ed.), Psychodrama: Advances in theory and practice (pp. 175-189). London: Routledge.

Hudgins, M. K., \& Toscani, F. (2013). Healing world trauma with the Therapeutic Spiral Model: Psychodramatic stories from the frontlines. Philadelphia: Jessica Kingsley.

Johnson, P. E. (1948). The psychodrama of God by J. L. Moreno. Journal of Bible and Religion, 16(4), 244-246.

Jones, P. (1996). Drama as therapy: Theory, practice and research. New York: Routledge. Jung, C. G. (1934). The collected works of C. G. Jung. London, New York: Routledge.

Jung, C. G. (1964). Man and his symbols. New York: Doubleday.

Jung, C. G. (2014). The archetypes and the collective unconscious. London: Routledge.

Jung, C. G. (2017). Mandala symbolism. (R. F. C. Hull, Trans.) Princeton: Princeton University Press.

Karp, M. (2005). An introduction to psychodrama. M. Karp, P. Holmes, \& K. B. Tauvon (Ed.), The handbook of psychodrama (pp. 3-15). East Sussex: Routledge.

Tahar, E., \& Kellermann, F. P. (1996). Psychodrama and drama therapy: A comparison. The Arts in Psychotherapy, 23(1), 27-36.

Kellerman, F. P. (1992). Focus on psychodrama: Therapeutic aspects of pychodrama. Philadelphia: Jessica Kingsley.

Gasseau, M. \& L. Perrotta (2013). The Jungian approach: in situ supervision of psychodrama. Krall, H., Fürst, J., \& Fontaine, P. (Ed.). (2013). Supervision in psychodrama (pp. 37-57). Wiesbaden: Springer.

Kraus, C. (1984). Psychodrama for fallen gods: a review of Morenian theology. Journal of group psychotherapy, psychodrama and sociometry, 37(2), 47-66.

Lawrence, W. G. (Ed.). (2003). Experiences in social dreaming. New York: Karnac. Leventon, E. (2001). A clinician's guide to psychodrama. New York: Springer.

Lindqvist, M. (2005). Religion and the spirit. P. Holmes, M. Karp, \& M. Watson (Ed.),

Psychodrama since Moreno (pp.137-153). New York: Routledge.

Marineau, R. F. (1989). Jacob Levy Moreno 1889-1974: Father of psychodrama, sociometry, and group psychotherapy. New York: Routledge.

Meyer, D. D. (2012). Techniques for spiritual, ethical, and religious counseling. Counseling and Value, 57(10), 241-252.

Miller, C. (2000). The technique of Souldrama and its applications. Journal of Group Psychotherapy, Psychodrama and Sociometry, 52(4), 173-186.

Miller, C. (2004). Souldrama: A journey into the heart of God. NJ: Self-published.

Miller, C. (2007). Psychodrama, spirituality and Souldrama. C. Baim, J. Burmeister, \& M. Maciel (Ed.), Psychodrama: Advances in theory and practice (pp. 189-201). London: Routledge. 
Miller, C. (2008). Souldrama ${ }^{\circledR: ~ S p i r i t u a l i t y ~ i n ~ a c t i o n . ~ J o u r n a l ~ o f ~ C r e a t i v i t y ~ i n ~ M e n t a l ~ H e a l t h, ~ 3(2), ~}$ 139-156.

Miller, C. (2010). Starve the ego: Feed the soul! Souldrama. Roseburg: Lulu.

Miller, C. (2013). Integrating two models for the treatment of addictions: Souldrama and 12- step recovery in action. Journal Of Groups In Addiction \& Recovery, 8(2), 81-111.

Moore, T. (1994). Soulmates honoring the mysteries of love and relationship. New York: HarperCollins.

Moore, T. (1996). The re-enchantment of everyday life. New York: HarperCollins.

Moreno, J. L. (1934). Who shall survive? A new approach to the problem of human interrelations. Washington: Mental Disease Publishing.

Moreno, J. L. (1946). Psychodrama. New York: Beacon House.

Moreno, J. L. (1947). Contributions of sociometry to research methodology in sociology. American Sociological Review, 12(3), 287-292.

Moreno, J. L. (1956). The sociometric school and the science of man. Sociometry, 18(4), 271- 291.

Moreno, J. L. (1961). The role concept, a bridge between psychiatry and sociology. American Journal of Psychiatry, 118(6), 518-523.

Moreno, J. L. (1971). Words of the Father. New York: Beacon House.

Moreno, Z. T., Blomkvist, L. D., \& Rutzel, T. (2013). Psychodrama, surplus reality and the art of healing. New York: Routledge.

Nicholas, M. W. (2017). The use of psychodrama and sociometry techniques in psychodynamic and other process groups. International Journal of Group Psychotherapy, 67, 131-140. doi: 10.1080/00207284.2016.1238751.

Perrotta, L. (2012). Transgenerational violence against women: Jungian psychodrama on the path to individuation. Interdisciplinary Journal of Family Studies, 17(2), 335-338.

Pitzele, P. A. (1991). The psychodrama of the bible: Mirror and window of soul. Religious Education, 86(4), 562-570.

Rosenbaum, M., \& Berger, M. (Ed.). (1963). Group psychotherapy and group function. New York: Basic Books.

Salehi, M., \& Shokri, M. (2016). The group psychodrama consultation effect on resiliency and spiritual intelligence of Eight grade female students. European Online Journal of Natural and Social Sciences: Proceedings, 5(3), 164-170.

Scategni, W. (1994). Das Psychodrama zwischett alltaglicher and arehetypischer Er/ahrungswelt. Solothurn and Dusseldorf: Walter Verlag.

Scategni, W. (2001). The social dream in psychodrama. Turin: Ananke.

Scategni, W. (2002). Psychodrama, group processes, and dreams: Archetypal images of individuation. (V. Marsicano, Trans.) New York: Taylor\&Francis.

Scheiffele, E. (1997). The theatre of truth: Psychodrama, spontaneity and improvisation; the theatrical theories and influences of Jacob Levy Moreno. Research in Drama Education, 2(2), 227.

Steere, D. A. (1997). Spiritual presence in psychotherapy: A guide for caregivers. New York: Routledge.

Tauvon, K. B. (2005). The protagonist. M. Karp, P. Holmes, \& K. B. Tauvon (Ed.), The handbook of psychodrama (pp. 97-117). East Sussex: Routledge. 
Tavakoly, F. M., Namdari, K., \& Esmaili, M. (2014). Effect of psychodrama-based group training for healthy lifestyle on psychological balance, spiritual well-being and optimism. Journal of Life Science and Biomedicine, 4, 346-351.

Tatham, P., \& Morgan, H. (2018). Social dreaming. New York: Routledge.

Waldl, R. (2005) J. L. Moreno's einfluss auf Martin Buber's Ich und Du [J. L. Moreno's influence on Martin Buber's I and Thou], Zeitschrift für Psychodrama und Soziometrie, 4(1), 175-191.

Wilkins, P. (1999). Psychodrama. London: SAGE.

Williams, A. (1991). Forbidden agendas: Strategic action in groups. East Sussex: Routledge.

Winters, N. (2000). The psychospiritual in psychodrama: A fourth role category. The International Journal of Action Methods, 52(4), 163-171.

Wolinsky, S. (1991). Trances people live. Connecticut: Bramble Company.

Yalom, I. D. (1995). The theory and practice of group psychotherapy. New York: Basic.

Yaniv, D. (2014). Tele and the social atom. Zeitschrift für Psychodrama und Soziometrie, 13(1), 107-120.

Zohar, D., \& Marshall, I. N. (1990). The quantum self: Human nature and consciousness defined by the new physics. New York: William Morrow \& Company.

Zohar, D., Marshall, I., \& Marshall, I. N. (2000). SQ: Connecting with our spiritual intelligence. New York: Bloomsbury Publishing.

Zoran D., Veljković J., \& Tovic, M. (2006). Psychodrama: A beginner's guide. Philadelphia: Jessica Kingsley.

Zuretti, M. (2005). The co-unconscious. P. Holmes, M. Karp \& M. Watson (Ed.),

Psychodrama since Moreno (pp. 153-168). New York: Routledge. 
